\title{
\#3
}

\section{Idealisme, Data, dan Model Bisnis}

\author{
Anna Agustina, Suhetris, \\ \& Alfito Deannova Ginting
}

Diskusi terkait model bisnis muncul sejak penyerapan teknologi di level mikro, meso dan makro terjadi. Teknologi mengubah proses produksi, transmisi, dan distribusi berbagai produk barang, jasa, dan perilaku individu dan organisasi. Kondisi ini kemudian memaksa individu dan organisasi untuk beradaptasi dengan mencari, dan merumuskan model bisnis baru yang kompatibel dengan konteks yang baru ini dalam rangka menjaga eksistensi.

Agar tak lekang, dan tetap kompetitif, model bisnis yang baru menjadi penting untuk dikaji dan diidentifikasi. Sumber daya, dan pertimbangan untung-rugi menjadi faktor dasar yang umum dijadikan pertimbangan dari sebuah bisnis model. Namun sebagai organisasi media yang juga memiliki idealisme menjunjung kepentingan yang lebih besar dan berkelanjutan dengan pedoman harus berdasarkan realitas yang telah dikonfirmasi menjadi faktor yang tidak kalah penting. Teknologi itu sendiri juga memiliki 
karakteristik yang dibawanya, seperti investasi tinggi namun inovasi dan kompetisi yang terus dilakukan membuat teknologi cepat berubah, adalah hal baru bagi berbagai jenis usaha yang akan dijadikan bisnis. Rentang waktu untuk perencanaan bisnis, implementasi, dan evaluasi untuk adaptasi menjadi sangat pendek. Komponen pengelolaan dan kontrol dalam empat komponen manajemen bisnis (Planning, Organizing, Actuating, Control) menjadi sulit untuk dikendalikan dengan adanya banyak perubahan yang terjadi dalam waktu yang cepat.

Isu 'kendali' menjadi sentral dalam diskusi model bisnis di era perubahan yang sangat cepat karena tehnologi memberikan banyak pilihan bagi semua pihak. Industri media menjadi salah satu pemangku kepentingan yang mengalami hilang kendali. Media tidak lagi menjadi pusat informasi peristiwa. Jurnalis tidak lagi memiliki privilege sebagai pihak pertama yang menyampaikan peristiwa di lain tempat kepada publiknya. Teknologi memungkinkan setiap individu untuk melakukannya. Teknologi memungkinkan setiap individu memproduksi informasi, memilih media penyebaran informasi yang diproduksinya, serta kapan dan kepada siapa ia membagikan informasi tersebut. Perilaku yang dulunya hanya mungkin dilakukan di level meso dan makro atau di level organisasi media/lembaga/institusi dengan aturan organisasi yang formal berbada hukum, dengan tambahan perhitungan untung-rugi, kini dapat dilakukan di level mikro yang rentang perhitungan untung-ruginya lebar dari yang abstrak-immaterial hingga material yang dulu hanya dimungkinkan terjadi pada level meso hingga makro. Level makro, umumnya dianalogikan dengan bentuk Negara. Hingga saat ini, level makro batasan definisi dan cakupannya masih disepakati warga bumi, sehingga belum ada isu kendali. Lalu bagaimana level meso? Dalam hal ini industri media dapat memasukkan faktor untung-rugi dalam berbisnis ketika level mikro sudah merebak dan perannya berubah menjadi pilihan bagi yang dulunya publik media? 
Apakah konsep publik media masih ada? Pada level media yang berletak di level meso, apa publik media tertentu masih relevan dalam konteks dimana individu memiliki kendali utama dalam memilih informasi, data, berita yang disukai melalui media yang memberikan fitur mudah di-klik? Konsep publik di level mikro bisa dilihat dengan adanya ikon like, subscribes, atau followers akun media sosial individu atau unggahan individu. Konsep publik level makro pun masih ada dengan masih relevannya konsep yang dikelompokkan seperti warganegara Indonesia, Malaysia, Suriname, dan sebagainya. Lalu, konsep publik di level meso bagaimana? Ini hal lain yang perlu dibicarakan kemudian, tidak pada artikel ini.

Artikel ini membatasi organisasi media, yang berada pada level meso, dan kini statusnya berubah dari pusat informasi, menjadi salah satu media pilihan bagi mantan publiknya mengingat publiknya dapat melakukan hal yang sama dengan organisasi media. Individu yang dulu menjadi publik media, penerima pesan, kini menjadi produser pesan, dan pemilih pesan yang tersedia di beragam platform. Sementara, disisi lain organisasi media memiliki tanggungjawab yang tetap sama. Peraturan, undangundang, etika yang dirujuk dan dijadikan dasar perilaku organisasi dan insan media tetap sama, meski diluar itu semua sudah berubah. Harapan masyarakat pada organisasi media dan insan media juga sama, menjadi pilar ke empat dari pemerintah yang berkuasa, pengawas penguasa, dan menjadi pihak yang dapat menyuarakan kelompok yang tertindas/terpinggirkan/terlupakan, serta memperjuangkan kepentingan masyarakat demi kesejahteraan dan keberlanjutan pembangunan. Kondisi realistis dan idealis ini kemudian mendorong pihak-pihak yang memiliki relasi pada organisasi dan insan media, berpikir pentingnya pemikiran perumusan model bisnis baru bagi media, agar organisasi dan insan media tak lekang. Sub bab berikut menggambarkan model bisnis secara umum, kemudian diikuti model bisnis media, 
kemudian ditutup dengan deskripsi model bisnis hasil observasi dan wawancara penulis terkait model bisnis media di Indonesia.

\section{Model Bisnis}

Kajian model bisnis yang ditemukan dalam literature, banyak yang merujuk pada kajiam Timmers (1998) yang melihat penggabungan bisnis dan tehkologi mendorong perlunya pembaruan pemikiran model bisnis. la mendefisinikan model bisnis sebagai: "an architecture for the product, service and information flows, including a description of the various business actors and their roles; and a description of the potential benefits for the various business actors; and a description of the sources of revenues" (p.4). Produk, pelayanan, alur informasi, para aktor bisnis, kuntungan potensial dan pendapatan menjadi unsur yang mengemuka dalam definisi model bisnis Timmer. Model bisnis sebagai bagian dari model pemasaran, dan penggunan tehnologi dalam e-commerce $B 2 B$ (business to business) dan B2C Business to Customers) adalah konteks batasan kajian Timmer.

Hasil observasi Timmers pada perusahaan yang ada saat itu adalah ada 11 kategori model bisnis. Kesebelas kategori model bisnis ini kemudian di analisis dari dimensi tingkat inovasi dan integrasi fungsional. Matriks hasil kajian Timmers dari kategori model bisnis, dimensi inovasi, dan dimensi integrasi fungsional digambarkan dalam Tabel 1. Data Kajian Model Bisnis Timmers tahun 1998.

Table 1 Data Kajian Model Bisnis Timmer tahun 1998

\begin{tabular}{llll}
\hline $\begin{array}{l}11 \text { kategori model bisnis Timmers (1998) dan } \\
\text { deskripsi kegiatan dan revenue }\end{array}$ & $\begin{array}{l}\text { Tingkat } \\
\text { inovasi }\end{array}$ & $\begin{array}{l}\text { Integrasi } \\
\text { fungsional }\end{array}$ \\
\hline 1.E-shop & $\begin{array}{l}\text { Promotion, cost reduction, } \\
\text { additional outlet (seeking } \\
\text { demand)-revenue on on }\end{array}$ & Satu fungsi \\
reduces cost, increase sales & & \\
and possibly advertising & & \\
\hline
\end{tabular}




\begin{tabular}{|c|c|c|c|}
\hline 2. E-procurement & $\begin{array}{l}\text { Additional in-let (seeking } \\
\text { supplies) - income from } \\
\text { reduction of cost - more } \\
\text { cost effective offers on } \\
\text { transaction of goods and } \\
\text { services. }\end{array}$ & Rendah & Satu fungsi \\
\hline 3. E-auction & $\begin{array}{l}\text { Electronic bidding (no need } \\
\text { prior movement of goods or } \\
\text { parties), income from selling } \\
\text { the technology platform, } \\
\text { transaction fee, and } \\
\text { advertising. Provide } \\
\text { efficiency and time-saving } \\
\text { value with global access. }\end{array}$ & Agak tinggi & Satu fungsi \\
\hline 4. E-mall & $\begin{array}{l}\text { Collection of e-shop, } \\
\text { aggregators, industry sector } \\
\text { marketplace - revenue from } \\
\text { membership } \\
\text { advertising, and fee on } \\
\text { transactions }\end{array}$ & Rendah & Satu fungsi \\
\hline $\begin{array}{l}\text { 5. } 3^{\text {rd }} \text { party } \\
\text { marketplace }\end{array}$ & $\begin{array}{l}\text { Common marketing front- } \\
\text { end and transaction support } \\
\text { to multiple businesses - } \\
\text { revenue: one-off } \\
\text { membership fee, service fee, } \\
\text { transaction fee, or } \\
\text { percentage on transaction } \\
\text { value. Revenue from one-off } \\
\text { membership fee, service fee, } \\
\text { transaction fee or } \\
\text { percentage on transaction } \\
\text { value. }\end{array}$ & Tinggi & $\begin{array}{l}\text { Beberapa } \\
\text { fungsi }\end{array}$ \\
\hline $\begin{array}{l}6 . \quad \text { Virtual } \\
\text { communities }\end{array}$ & $\begin{array}{l}\text { Focus on added-value of } \\
\text { communication between } \\
\text { members - the ultimate } \\
\text { value from members - } \\
\text { customers or partners. } \\
\text { Membership fee and } \\
\text { advertising } \\
\text { revenue. }\end{array}$ & Tinggi & $\begin{array}{l}\text { Beberapa } \\
\text { fungsi }\end{array}$ \\
\hline
\end{tabular}




\begin{tabular}{|c|c|c|c|}
\hline $\begin{array}{l}\text { 7. Value chain } \\
\text { service provider }\end{array}$ & $\begin{array}{l}\text { Support part of value chain, } \\
\text { e.g. logistic, payments - } \\
\text { revenue on the percentage } \\
\text { based scheme. }\end{array}$ & Tinggi & Satu fungsi \\
\hline $\begin{array}{l}\text { 8. Value change } \\
\text { integrator }\end{array}$ & $\begin{array}{l}\text { Added-value by integrating } \\
\text { multiple steps of the value } \\
\text { chain. Revenue comes from } \\
\text { consultancy and transaction } \\
\text { fees. }\end{array}$ & Tinggi & $\begin{array}{l}\text { Beberapa } \\
\text { fungsi }\end{array}$ \\
\hline $\begin{array}{l}\text { 9. Collaboration } \\
\text { platforms }\end{array}$ & $\begin{array}{l}\text { e.g. collaborative design. } \\
\text { Business opportunity } \\
\text { managing the platform } \\
\text { (membership/usage fee), } \\
\text { and in selling the specialist } \\
\text { tools (workflow, design, } \\
\text { document management, } \\
\text { etc.) }\end{array}$ & Tinggi & $\begin{array}{l}\text { Beberapa } \\
\text { fungsi }\end{array}$ \\
\hline $\begin{array}{l}10 . \text { Information } \\
\text { brokers }\end{array}$ & $\begin{array}{l}\text { Added-value to the huge } \\
\text { amount of data such as } \\
\text { information search, e.g. } \\
\text { yahoo, customer profiling, } \\
\text { investment advice, etc. - } \\
\text { directly paid for either } \\
\text { through subscription or on } \\
\text { pay-per-use basis }\end{array}$ & Tinggi & Satu fungsi \\
\hline $\begin{array}{l}\text { 11. Trust and } \\
\text { other services }\end{array}$ & $\begin{array}{l}\text { Trust providers, business } \\
\text { information and } \\
\text { consultancy - revenue from } \\
\text { subscription fee combined } \\
\text { with one-off service, } \\
\text { software sales, and } \\
\text { consultancy. }\end{array}$ & Tinggi & Satu fungsi \\
\hline
\end{tabular}

Sumber: Data hasil olahan kembali penulis dari artikel Timmers tahun 1998.

Unsur produk, pelayanan, alur informasi, para aktor bisnis, kuntungan potensial dan pendapatan menjadi dasar pengkategorisn model bisnis Timmer sesuai dengan definisinya. Dimensi inovasi dan integrasi fungsi digunakan untuk menganalisis perbedaan model bisnis yang lalu dan model bisnis yang baru. 
Kajian literatur tentang model bisnis yang dilakukan Alt dan Zimmerman (2001) menyatakan tidak adanya kesepakatn tentang definisi model bisnis. Namun mereka menjelaskan salah satu indikator bahasan suksesnya model bisnis adalah adanya keterlibatan tehnologi dan aktor-aktor yang ada di dalamnya. Simpulan dan hasil kajian mereka adalah penyajian 6 elemen generic dalam model bisnis yaitu: misi (mission), struktur (structure), proses (processes), pendapatan (revenues), isu legal (Legal issues), dan teknologi. Dua elemen terakhir adalah elemen yang dianggap dapat menunjang atau menyulitkan 4 elemen pertama. Keenam elemen model bisnis ini dianggap sebagai kerangka komprehensif dalam membangun model bisnis yang berkelanjutan dalam lingkungan pasar elektronik. Dan ketika mengimplementasikan keenam elemen model bisnis tersebut kedua peneliti juga mengingatkan untuk memperhatikan dinamika yang terjadi antar element sebagai bahan pertimbangan pembangunan model bisnis.

Al-Debei dan Avison (2010) melakukan kajian kerangka konsep model bisnis dengan metode analisis isi literatur tentang model bisnis. Salah satu hasil kajiannya menjabarkan bahwa kajian-kajian terdahulu memetakan bahwa model bisnis mencakup: 4 dimensi nilai, fungsi model bisnis, daya jangkau model bisnis, dan prinsipprinsip modeling. Hasil yang menarik dari kajian Al-Debei dan Avison adalah pada mapannya konsep model bisnis dengan dimensi dan indikatornya. Konsep model bisnis memiliki dimensi empat stuktur ontologis nilai (value ontological structure) yang menjadi dimensi utama dari konsep model bisnis, yaitu value proposition (1), value network (2), value architecture (3), dan value finance (4). Masing-masing dimensi ini memiliki indikator berikut: (a). Value proposition (offering value structure): Product Service, intended-value element, dan target segment; (b). Value network (business and customer actors web), adalah nilai yang sejalan dengan yang dijelaskan Timmers, terdiri dari actor, peran, 
hubungan, alur komunikasi, media/channel, pengelolaan, dan network-mode; (c). Value architecture (technological architecture and organizational infrastructure) memiliki indikator: sumber daya utama, value-configuration, dan core competency; (d). Value finance (financial ser-ups and returns) terdiri dari indikator: total cost of ownership, pricing method, dan revenue structure.

Konsep bisnis model, dengan 4 dimensi dan indikator hasil kajian Al-Debei dan Avison ini adalah salah satu hasil yang disajikan untuk mempermudah kajian model bisnis berikutnya bagi pendekatan lainnya, meski pendekatan utama yang mereka gunakan adalah pendekatan kaiian sistim informasi. Mereka menyatakan bahwa hasil kajian literaturenya dapat digunakan untuk pendekatan lain mengingat diskusi tentang model bisnis baru muncul karena adanya teknologi dan penerapan teknologi dalam organisasi di konteks yang saat ini sangat dinamis. Penjelasan Al-Debei dan Avison ini kemudian sejalan dengan penjelasan yang diberikan oleh Burkhart, dkk. yang dipaparkan pada konferensi kedua sistem informasi di Shanghai tahun 2011 dan makalahnya diunggah online tahun 2014 oleh Dirk Werth sebagai salah satu peneliti dan penulisnya. Mereka menyinggung penggunaan tehnologi komunikasi mendorong munculnya bisnis baru. Bisnis dalam bentuk dot.com muncul dimana-mana di era 2000an. Sehingga saat itu faktor tehnologi dan inovasi dianggap menjadi unsur penting dalam model bisnis. Namun adanya dot.com bubble yang menjadikan bisnis dot.com berakhir, membuat para pengkaji model bisnis kembali mempertanyakan faktor penting dalam model bisnis.

Kajian literatur Burkhart, dkk (2011) diawali dengan faktor penggunaan teknologi dan inovasi sebagai indikator penting dalam model bisnis, sejalan dengan Timmers dan Al-Debei, dkk. Namun dalam simpulan kajiannya, Burkhart, dkk. melihat belum adanya keajegan faktor-faktor dalam model bisnis dan kajian tentang keterkaitan dari komponen-komponen model bisnis sehingga 
belum ada formula yang dapat diajukan sebagai representasi model bisnis yang disepakati baik dalam bentuk grafik maupun tekstual. Sehingga Burkhart, dkk. menyarankan perlu dilakukan kajian empiris dengan skala yang lebih besar untuk mengidentifikasikan hal tersebut.

\section{Model Bisnis Media}

Artikel ini melihat model bisnis dalam pendekatan induktif organisasi media. Dengan populasi media yang ada di Indonesia, dan purposive sampling pembuat keputusan dalam organisasi media yang bersedia di wawancara oleh tim penulis dalam waktu 3 bulan sejak Januari hingga Maret 2021. Waktu dimana menjelang satu tahun pandemi di Indonesia (Maret 1 tahun), penggunaan media meningkat dalam jumlah yang akses media, namun insan media terbatas dalam melakukan interaksi liputan. Tidak bermaksud membandingkan, namun jika ada data yang mengubah model bisnis media saat pandemi, maka hal ini menjadi menarik untuk di narasikan dalam temuan sebagai tambahan tujuan utama artikel yaitu menggambarkan model bisnis media di Indonesia dari dimensi value network dimana aktor, hubungan, peran, dan point of revenues menjadi indikatornya.

Mengacu pada kajian model bisnis, organisasi media di Indonesia telah masuk dalam kategori menggunakan teknologi dan berinovasi dalam proses produksi, distribusi dan transmisi. Salah satu motivasi penggunaan teknologi adalah efisiensi dan peningkatan pendapatan. Mengacu pada adopsi teknologi mengubah model bisnis serta pentingnya aktor di dalamnya (Timmers, 1998; Al-Debei dan Avison, 2010). Kajian model bisnis media di Indonesia juga menghubungkan unsur aktor, dan unsur adopsi teknologi. Beberapa kajian terdahulu tentang adopsi teknologi yang dilakukan media-media di Indonesia menggambarkan implikasinya adalah pada perubahan aktor media, dan proses jurnalistik yang dilakukan 
oleh organisasi media (Wibawa, dkk. 2010; Agustina, 2018; Ginting, dkk., 2020).

Aktor dalam bisnis media tercermin dalam pemilik media yang membentuk lanskap media di Indonesia menjadi bersifat konglomerasi dan mengarah pada oligopoly (Lim, 2012). Aktor dalam kajian model bisnis penyiaran TV digital di Indonesia (Wibawa, dkk., 2010) membahas ketidakpuasan penonton terkait konten TV, dan perlunya bisnis model yang berbeda antara dua aktor penyelenggara penyiaran, yaitu TVRI yang merupakan TV publik Indonesia, dan TV swasta sebagai konsekuensi dari adanya perubahan teknologi analog ke digital serta penggunaan teknologi yang ditambahkan dalam sistem penyiaran. Agustina (2018) mengidentifikasi pemangku kepentingan media yang semakin beragam akibat diadopisnya teknologi oleh organisasi media. Pemangku kepentingan yang beragam muncul pada tiap lini kegiatan media. Pertama pada skenario kepemilikan saham media, atau partner dalam bentuk bagi hasil, ataupun dalam bentuk kerjasama. Skema partner dapat dilakukan mulai dari pembuatan konten, kemudian penentuan channel/saluran/alat yang digunakan untuk akses seperti gadget/laptop/TV/telepon pintar yang digunakan, kemudian penyedia jasa telekomunikasi, hingga aplikasi yang akses pengguna. Kajian-kajian ini melihat lebih rinci tentang adanya perubahan-perubahan aktor ketika teknologi diadopsi oleh media. Namun belum ada yang mengidentifikasi tentang model bisnis yang berkaitan dengan kajian Timmers ataupun Al-Debei dan Avison dengan kerangka berpikir pada dimensi value network.

Value network menarik untuk dikaji. Apalagi jika mengingat Lim (2012) menyebutkan bahwa antara tahun 1998 hingga tahun 2002, Indonesia menjadi tuan rumah dari lebih dari 1200 media cetak baru, lebih dari 900 radio komersial baru, dan 5 TV komersial baru yang hampir seluruh media didominasi oleh kepentingan korporasi. Media yang begitu banyak dan beragam, jika dilihat pemiliknya akan mengerucut menjadi 12 pemilik yang merupakan entitas komersial, 
dan 1 milik Negara dengan status publik. Dimensi value network dalam artikel menjadi pedoman dalam menganalisis data dalam artikel ini yang diambil dari wawancara beberapa informan dari beberapa media di Indonesia. Deskripsi mencakup indikator dari konsep model bisnis dari dimensi nilai jejaring (value network), yaitu: aktor, hubungan, peran, dan point of revenues.

\section{Hasil}

Empat informan kajian artikel ini berasal dari organisasi media TV swasta (1), TV publik (2), kelompok media berita dan lifestyle (3), serta organisasi media yang merupakan bagian kelompok bisnis holding (4). Seluruh informan menjelaskan bahwa organisasi medianya telah mengadopsi tehnologi. Inovasi yang dilakukan dengan adanya teknologi tersebut memiliki rentang yang besar sehingga ada yang organisasi media yang sampai merubah nama, sementara lainnya tetap sama. Peningkatan jumlah aktor (pemangku kepentingan) yang berinteraksi dengan organisasi media terjadi di keempat media, namun jenis hubungan yang ada di level organisasi media tetap sama, seperti karyawan tetap/kontrak, media-penonton, media-subscribers, media-pengiklan, dan penjual pembeli, semua berdasarkan transaksional antara media dan pemangku kepentingan lainnya.

Rentang inovasi dari yang sangat cepat berubah dan mengembangkan bisnis berkat adanya adopsi teknologi adalah informan 4. Meski dimiliki menjadi bagian dari holding usaha lain selain media, informan 4 menggambarkan bahwa holding tidak masuk dalam kebijakan redaksi. Inovasi hasil adopsi teknologi membuat organisasi media informan 4 memiliki pembeda dari media lain yaitu, jurnalisme data, pengelola data, yang kemudian berkembang menjadi penyedia data. Pemangku kepentingan media bertambah, sebagai akibat dari munculnya unit bisnis baru yaitu penyedia data yang dapat dibeli oleh organisasi lain. Organisasi media memiliki divisi berbeda, redaksi yang memproduksi berita 
yang penekanannya pada bentuk jurnalisme data, dan pengelola dan penyedia data. Hal ini otomatis menciptakan point of revenue yang baru bagi media dimana ia bekerja, dan pemangku kepentingan yang perannya sebagai pembeli data atau pembeli jasa pengelolaan data. Sementara redaksi tidak terlibat dengan hal ini mengingat divisinya berbeda. Idealisme jurnalis berkembang dengan pentingnya data yang menjadi dasar berita, pendukung berita, dan peristiwa yang dirujuk, dengan tetap mewajibkan pendekatan nara sumber baru yang mencirikan crown jurnalisme yaitu cek-re-cek dan konfirmasi data pada saat berita akan ditayangkan.

TV publik pun menjalankan hal yang sama. Mereka melakukan inovasi dengan mengembangkan media berita portal, dengan tim yang hubungannya diatur dalam kontrak yang biasa mereka lakukan. Bedanya saat ini TV publik sedang bertahap menerapkan sistem yang baru dari yang dulunya struktural kini berubah menjadi fungsional. Peran atasan-bawahan tetap ada ditambah dengan hubungan yang perannya kolegial dalam kerja tim. Inovasi ini diakui bukan saja karena teknologi, namun juga karena adanya kebijakan baru. Bagi TV publik, point of revenue tetap mengacu pada peraturan penerimaan nasional bukan pajak (PNBP). Perubahan yang terjadi dalam point of revenue dalam konteks model bisnis perlu dikaji dan ditetapkan oleh Dewan Pengawas untuk kemudian dilihat kemungkinannya untuk diterapkan. Dalam konteks ini, terbayang idealisme media cenderung akan tetap sama, meski divisi baru dengan tim baru yang melibatkan milenial telah mewarnai berita portal di satu-satunya TV publik di Indonesia.

Informan 1 dari TV swasta dan informan 3 dari kelompok media berita dan lifestyle menjelaskan bahwa struktur organisasi mereka tidak berubah dengan peran yang juga relative sama. Adopsi teknologi membuat proses produksi otomatis menjadi digital, dengan pola hubungan kerja yang relatif sama, dan juga peran yang relatif sama pada level organisasi media. Bedanya, informan 1 di TV 
swasta menjelaskan point of sales cenderung tetap sama, mengingat beberapa indikator bisnisnya saat ini tetap sama, seperti target pemirsanya masih relatif sama di Indonesia; sedangkan informan 3 yang bisnis organisasinya sejak awal adalah online menjelaskan bahwa adanya media sosial dan penggabungan media sosial dengan media online, sebenarnya memunculkan banyak point of sales baru. Namun sebagai organisasi media berita, redaksi masih menekankan menjaga konten media agar tetap melakukan cek-recek serta konfirmasi peristiwa. Satu hal lagi yang hingga saat ini redaksi tekankan adalah menjaga etika media. Jika sebelum digitalisasi dan media sosial mewarnai, kedua hal ini membuat insan media dan organisasi media sering berkunjung kedewan pers, saat ini penjagaannya makin tidak mudah.

\section{Idealisme dan Model Bisnis media}

Dari 4 indikator model bisnis dalam nilai jejaring yang dijelaskan oleh Al-Debei dan Avison (2018), insan media yang menjadi informan menangkap bahwa adopsi tehnologi menyebabkan adanya perubahan. Perubahan yang langsung terlihat adalah pada bertambahnya tehnologi, bertambahnya pelaku kepentingan baru meski cenderung pada peran dan jenis hubungannya tetap sama. Peran dan jenis hubungan yang sama ini kemudian cenderung tidak menciptakan point of sales yang baru, kecuali pada satu informan.

Satu informan menjelaskan bahwa organisasi medianya berani mengubah model bisnis dengan mengubah nama organisasi dan struktur organisasi dengan menambah divisi yang membedakan divisi dengan kerja jurnalistik dan divisi yang meningkatkan point of sales untuk menjada idealisme. Tiga informan lainnya menjelaskan bahwa model bisnis yang dijalankan cenderung sama antara sebelum dan sesudah adopsi teknologi. Juga idealisme yang harus tetap dijunjung menjadi pedoman semua informan. Namun prakteknya dijelaskan sesuai konteks masing-masing. Satu media melalui monitoring dan evaluasi mengingat media sosial dan 
digitalisasi memungkinkan muncul masalah etika yang tak terasa dilampaui. Dua media lainnya melalui taat asas dan peraturan yang berlaku dalam organisasinya, kedua media penyiaran menampilkan isu yang penting bagi kepentingan yang lebih besar, dengan tambahan TV publik tetap harus mengikuti kebijakan yang berubah seperti struktural menjadi fungsional dan peraturan terkait PNBP.

Adopsi teknologi belum tentu mendorong perlunya praktek model bisnis yang baru. Idealisme dalam organisasi media terlihat masih tetap dijaga meski terasa bayangan kesulitan menjaga idealisme tersebut dari yang disampaikan oleh para informan. Model bisnis bagi media online yang menjadi informan artikel ini terlihat ada 2 pilihan. Pertama adalah mengubah sama sekali organisasi media lalu memisahkan divisi jurnalisme dengan divisi bisnis yang menekankan point of sales dengan irisan kerja di data yang dapat digunakan oleh jurnalis maupun bisnisnya. Kedua, mengembangkan diri dengan menambahkan point of sales bukan saja dari transaksi yang dimungkinkan terjadi pada organisasi media tradisional, tapi juga point of sales dari media baru. Model bisnis di dua penyiaran TV mengimplikasikan cenderung tetap menggunakan model bisnis yang sama. Terlihat masih belum adanya penerapan model bisnis baru meski perencanaan tentang hal itu sudah ada.

\section{Temuan}

Beberapa hal penting ditemukan dalam data artikel ini adalah: (1) model bisnis organisasi media dapat berubah dengan mempertimbangkan data yang telah dikumpulkan oleh tehnologi; (2) data muncul sebagai isi konten dari irisan idealisme dan bisnis; (3) media lama dan media sosial dapat menjadi ladang pengumpulan data yang dimungkinkan menjadi point of sales baru; inovasi pengelolaan data dapat menjadi item penting yang tidak mengganggu idealisme jurnalis meski model bisnis berubah (4). Temuan ini masih perlu diuji kembali dan dikaji kembali dengan 
menambahkan informan baru dari media lain mengingat media lain yang jumlahnya tidak sedikit di Indonesia. Selain itu artikel ini masih dibatasi dengan satu dimensi dimensi model, pelibatan bisnis lainnya menjadi penting untuk kajian berikutnya.

\section{Referensi}

Agustina, Anna. (2018). Redefinisi lapisan pemangku kepentingan media. Acta Diurna,

Al-Debei, Mutas M., Avison, David. (2010). Developing a unified framework of the business model concept, European Journal of Information Systems, 19, pp. 359-376.

Alt, Rainer, Zimmerman, Hans-Dieter. (2001). Business Models, EM-Electronic Markets, Vol 11(1), pp. 3-9.

Burkhart, Thomas, Werth, Dirk, Krumeich, Julian, dan Loos, Peter. (2011). Analyzing the business model concept - A Comprehensive classification of literature, Conference Paper: thirty Second International Conference on Information systems, Shanghai, 2011.

Ginting, Alfito, dkk. (2020) Pergeseran model bisnis media dan etika media: Era integrasi informasi, redaksi, tehnologi, dan proses jurnalistik, Coverage: Journal of Strategic Communication, Vol. 11 No. 1, hal. 12-18.

Lim, Merlyna. (2012). The league of thirteen: media concentration in Indonesia, Research report. Tempe, AZ: Participatory Media Lab at Arizona State University.

http://www.public.asu.edu/ mlim4/files/Lim_IndoMediaOwnership_20 12.pdf.

Timmers, Paul. (1998). Business Models for electronic Markets, E-CommerceNet, Research Note \#98-21, European Commission, Directorate-General III, published in September 1998.

Wibawa, Arif, dkk. (2010). Model bisnis penyiaran televise digital di Indonesia, Jurnal Ilmu Komunikasi, Vol. 8, Nomor 2, hal 117-130. 


\section{Profil Penulis}

Anna Agustina adalah dosen Fakultas Ilmu Komunikasi Universitas Pancasila (UP) sejak 2007. la menekuni profesi dosen berbarengan dengan profesi sebagai praktisi ilmu komunikasi (sejak 1990). Sebagai praktisi, Anna pernah menjadi asisten peneliti di LPPKM yang dikelola Prof Sasa Djuarsa, reporter magang di Tempo dan Kompas, PDAT Tempo, dan TVRI, penyiar radio Dakta, humas dan EO Nama Communication, dan konsultan bidang komunikasi. Mata kuliah yang diampunya antara lain Pengantar IImu Komunikasi, EFILKOM, dan Metodologi Kualitatif. Publikasinya antara lain: Resep menulis apa sudah ganti? Kangen Ragam Kata, Redefinisi lapisan pemangku kepentingan media, Environmental Communication in Indonesian Television Coverage, Public's Media Use and Gratification Sought during Corona Virus Outbreak in Indonesia. Kontak Anna: annaagustina@univpancasila.ac.id.

Suhetris, lahir di Padang pada tanggal 25 Maret tahun 1968. Menyelesaikan studi sarjana pada jurusan ilmu komunikasi di Fakultas IImu Sosial dan IImu Politik Universitas Indonesia pada tahun 1995, dan Master Program Administrasi Publik, Fakultas Ilmu Sosial dan Ilmu Politik, Universitas Padjadjaran tahun 2015. Mengawali karir sebagai Pegawai Negeri Sipil di Direktorat Pembinaan Wartawan, Departemen Penerangan pada tahun 1998 sampai dengan tahun 2001. Adanya kebijakan pemerintah untuk menhapuskan Departemen Penerangan di tahun 1999, mengubah karir Suhetris yang sejak tahun 2001 berkarya sebagai Pegawai Negeri Sipil di Kementerian Riset dan Teknologi. Sejak tahun 2020 ia diangkat menjadi Analis Kebijakan Ahli Madya di Kementerian Riset dan teknologi/Badan Riset dan Inovasi. Kontak email: hetris68@gmail.com.

Alfito Deannova Ginting adalah dosen FIKOM UP sejak 2007. Semangatnya memungkinkan FIKOM UP merekrut peserta didik sejak awal FIKOM UP dibangun. Setelah menyelesaikan studi sebagai Sarjana Ekonomi UI, profesi sebagai host acara di TV mendorongnya menyelesaikan S2 di Departemen Ilmu Komunikasi UI. Pada tahun 2007, profesi dosen di FIKOM UP dan praktisi bidang komunikasi diampunya hingga kini. Mata kuliah yang diampunya antara lain Jurnalistik, produksi Televisi, dan EFILKOM. Sebagai praktisi selain berperan sebagai jurnalis yang menduduki posisi manajerial di media portal yang pertama hadir di Indonesia, ia juga mengisi sesi pelatihan bidang komunikasi. Publikasinya antara lain tentang media aggregator di Indonesia, dan 
Model Bisnis Media. Imel kontaknya adalah alfitodeannova@univpancasila.ac.id. 